\title{
Industrial Life in a Limiting Landscape: An Environmental Interpretation of Stalinist Social Conditions in the Far North*
}

\author{
A N D Y B R U N O \\ History Department, University of Illinois at Urbana-Champaign \\ E-mail: andy.bruno@gmail.com
}

SUMMARY: This paper offers an environmental history of a group of forced migrants who were sent to work on a Soviet industrial project in the far north during the 1930s. As part of the drive to industrialize the country rapidly, the Soviet state deported thousands of peasants who had been declared class enemies to the previously desolate Khibiny Mountains in order to serve as the labor force for a new socialist mining town. These forced migrants became known as "special settlers". I argue that the integration of the environment as a dynamic force in the social history of Stalinism enriches current explanations for why the Soviet state was often unable to carry out its intentions during industrialization. I also maintain that through the pursuit of the global process of industrialization, the Soviet government contributed to making the special settlers in the Khibiny Mountains vulnerable to natural hazards.

After what she recalled was a happy childhood in a village in the Krasnodar region, L.E. Gudovskaia's life changed abruptly on a February night in 1930. Police came and arrested her father, E.A. Zinchenko, as a kulak - a comparatively well-off peasant deemed a class enemy by the Soviet state. Stripped of their property, the entire family was sent to the Urals region and forced to collect wood from the surrounding forests. At the end of the summer the government again relocated the family. Contrary to seventeen-year-old Gudovskaia's hope of returning home, they landed in

\footnotetext{
* I would like to express my appreciation to the many individuals who have read and commented on this manuscript at varying stages, including Alan Barenberg, Peter Boomgaard, Donald Filtzer, Sarah Frohardt-Lane, Zsuzsa Gille, Marjolein 't Hart, Diane Koenker, John Randolph, Jesse Ribot, Mark Steinberg, and Maria Todorova. The research for this essay was supported by an International Dissertation Research Fellowship from the Social Science Research Council with funds from the Andrew W. Mellon Foundation and with a fellowship from the US Student Fulbright Program.
} 
a new settlement in the Khibiny Mountains in the far north-west corner of the country. In the I990s she described their arrival to local members of the Memorial society:

The settlement at thirteenth kilometer, where we were unloaded, consisted of shalmany and tents. After sanitation processing and baths our families moved into a shalman. The shalman was built from boards and on the outside it was covered with roofing felt. On the sides there were plank beds. De-kulakized families already resided in this shalman. On the edges of the shalman stood two iron stoves. Lanterns lit the shalman. Our family took eight meters of space on the plank beds. We slept, ate, and sat on these boards. Sometimes, waking up on cold days, your hair would be frozen to the wall. ${ }^{\mathrm{I}}$

The family lived in this residence for two years while the father worked in a mine, extracting the phosphorous mineral apatite for fertilizer production, and Gudovskaia took various jobs. They survived on meager food rations and the mushrooms and berries they collected. Upon moving to an apartment, Gudovskaia summarized life during those first years:

[...] we, the kulaks, lived as morally dead, dejected people. Thousands of people went hungry and grieved in the tents and shalmany over the whistling of the raging northern wind, over the wailing blizzards, and, yes, over the cries of our own young children trembling from the cold in tarpaulin tents and in crowded, hard to heat, shalmany. ${ }^{2}$

\section{EXPLAINING STALINIST SOCIAL CONDITIONS}

Historians of the Soviet Union have interpreted the common stories of personal suffering in the I930s like Gudovskaia's in several ways. In works produced in the Soviet Union under the auspices of regime censorship, such accounts were often incorporated into heroic narratives of citizens struggling in adverse conditions to build socialism without any reference to the coerced character of their labor. ${ }^{3}$ For an array of other observers and scholars such indignities reflected the callousness of Joseph Stalin and other Soviet leaders and the inhuman character of the communist system. ${ }^{4}$ Hunger, the cold, and material deprivations were intentional elements of a campaign to punish the peasantry.

I. L.E. Gudovskaia, "Chto sokhranila pamiat", in Spetspereselentsy v Khibinakh: Spetspereselentsy $i$ zakliuchennye $v$ istorii osvoeniia Khibin (Kinga vospominanii) (Apatity, 1997), pp. 34-4I, 36 .

2. Ibid., p. 37 .

3. An example of this literature that discusses the industrialization of the Khibiny region is the first edition of A.V. Barabanov, A.A. Kiselev, and A.I. Krasnobaev, Gigant v Khibinakh: Istoriia ordena Lenina $i$ ordena Oktiabr'skoi revoliutsii proizvodstvennoi ob"edineniia “Apatit” im. S.M. Kirova (1929-1979) (Murmansk, I981).

4. Alexander Solzhenitsyn, The Gulag Archipelago, Thomas P. Whitney and Harry Willetts (trans.), 3 vols (New York, I973); Robert Conquest, The Great Terror: Stalin's Purges of the 


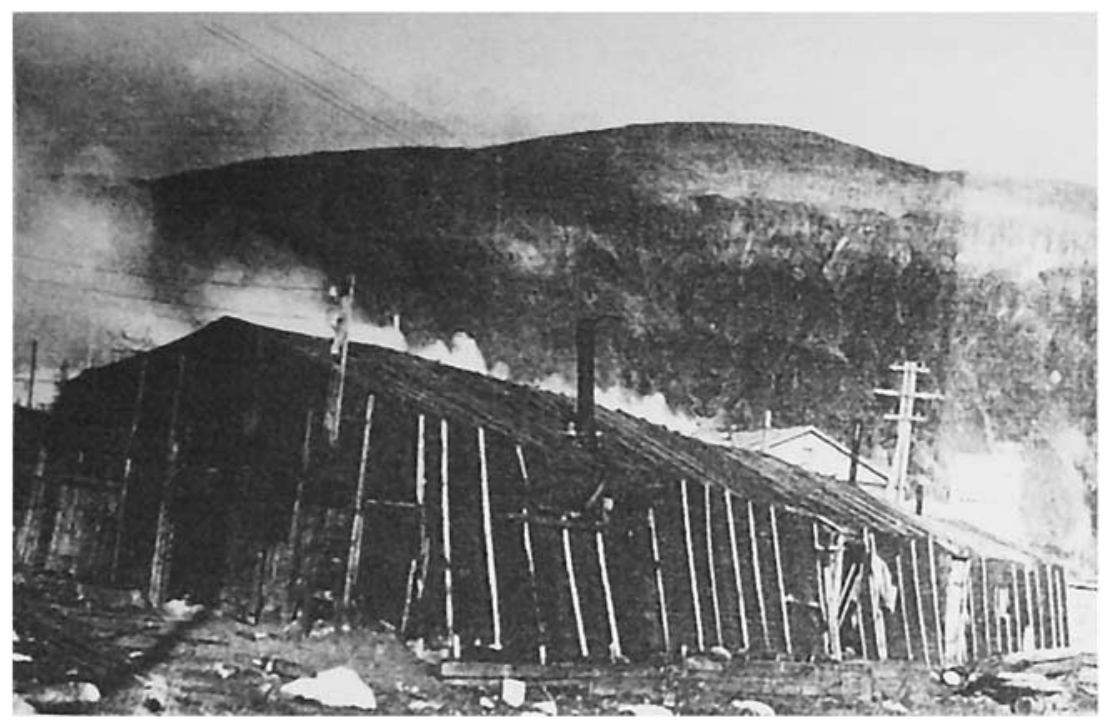

Figure I. Many "special settlers" in the Khibiny Mountains lived in ad hoc structures like this one made of boards and roofing. In Russian it was known as a shalman.

Source: Sergei Tararaksin, Sudeb sgorevshikh ochertan'e [Outlines of Burnt Fates] (Murmansk, 2006), p. 26.

Another line of scholarship takes intentional oppression as a given, but stresses the extent to which such brutality aligned with Soviet ideology. Stalinist industrialization relied on using rehabilitative labor to attempt to turn peasant class enemies into modern socialist citizens. ${ }^{5}$ The hubris that accompanied this desire to transform society rapidly and totally helped blind ideologues to the easily anticipated deprivations that would result from their schemes.

Historian Lynne Viola concurs with the assessments that emphasize the deliberately punitive elements of Soviet agrarian politics in the early I930s, labeling this era a "war on the peasantry". ${ }^{6}$ She, nevertheless,

Thirties (New York, I968); idem, The Harvest of Sorrow: Soviet Collectivization and the Terror-Famine (Oxford, 1987); Oleg V. Khlevniuk, The History of the Gulag: From Collectivization to the Great Terror (New Haven, CT, 2004); idem, The Master of the House: Stalin and His Inner Circle, Nora Seligman Favorov (trans.) (New Haven, CT, 2008). On the brutal social conditions of the 1930 and their connection to communist economic organization, see Elena Osokina, Our Daily Bread: Socialist Distribution and the Art of Survival in Stalin's Russia, 1927-194I (Armonk, NY, 200I).

5. Stephen Kotkin, Magnetic Mountain: Stalinism as a Civilization (Berkeley, CA, I995); David Hoffmann, Stalinist Values: The Cultural Norms of Soviet Modernity, I9I7-I94I (Ithaca, NY, 2003); Jochen Hellbeck, Revolution on My Mind: Writing a Diary Under Stalin (Cambridge, MA, 2006). 6. This phrase appears primarily in Viola's earlier works: Lynne Viola, Peasant Rebels Under Stalin: Collectivization and the Culture of Peasant Resistance (New York, 1996); idem et al. 
explains the hardships of former kulaks somewhat differently. In the first major English-language study of the fate of "special settlers" like Gudovskaia's family, Viola highlights the unintended consequences of policy decisions and the inability of the state to enact its will fully. ${ }^{7}$ This chaos undermined the imperatives of economic development. She also sees the role of re-education efforts as primarily rhetorical and therefore less constitutive of special settler experience than other scholars. Summarizing her position, Viola writes that the "combination of an infrastructurally weak state, an interventionist state bent on a totalizing vision of societal transformation (all too often in the abstract), and an ideological Weltanschauung of prejudice, fear, and limitless hatreds were at the roots of Stalinist repression". ${ }^{8}$ The interaction of these three factors explains the overall brutal experience of forced peasant migrants, including weatherrelated afflictions like the frozen trembling of Gudovskaia's younger brothers and sisters.

What is missing from these overall illuminating attempts to account for the miserable conditions faced by forced peasant migrants is an adequate assessment of the role of the natural environment in causing these hardships. The environment is more than a set of stable natural features of a place that obviously influence human populations. Instead, humans interact with the environment through a negotiated process. The responses of nature and social actors to changing circumstances frequently alter the situation further. ${ }^{9}$

The purpose of embracing this methodological perspective is twofold. First, it helps highlight the ubiquity and multifaceted significance of the environment in social history more thoroughly. The raging winds, wailing blizzards, and frozen hair of Gudovskaia's reflections become not only examples of human suffering, but key components of the world created by Stalinist modernization. Secondly, a focus on the responsiveness of the

(eds), The War Against the Peasantry, 1927-1930: The Tragedy of the Soviet Countryside (New Haven, CT, 2005).

7. Idem, The Unknown Gulag: The Lost World of Stalin's Special Settlements (Oxford, 2007). This interpretation aligns with much of the historiography on the social history of Stalinist industrialization. See, for example, Kendall Bailes, Technology and Society under Lenin and Stalin: Origins of the Soviet Technical Intelligentsia, 1917-194I (Princeton, NJ, 1978); Donald Filtzer, Soviet Workers and Stalinist Industrialization: The Formation of Modern Soviet Production Relations, 1928-194I (London, 1986); Hiroaki Kuromiya, Stalin's Industrial Revolution: Politics and Workers, 1928-1932 (Cambridge, 1988); David Shearer, Industry, State, and Society in Stalin's Russia, 1926-1934 (Ithaca, NY, 1996); Sheila Fitzpatrick, Everyday Stalinism: Ordinary Life in Extraordinary Times: Soviet Russia in the I930s (Oxford, 1999).

8. Viola, The Unknown Gulag, p. I90.

9. On how humans interact with nature through a negotiated process, see Timothy Mitchell, Rule of Experts: Egypt, Techno-Politics, Modernity (Berkeley, CA, 2002); Bruno Latour, Reassembling the Social: An Introduction to Actor-Network-Theory (Oxford, 2005); Zsuzsa Gille, From the Cult of Waste to the Trash Heap of History: The Politics of Waste in Socialist and Postsocialist Hungary (Bloomington, IN, 2007). 
environment enriches our perspective on the interplay of intentions and inadvertent results in this industrial project. The failure of initial government efforts to implement the intended punishment of former kulaks, which would have used them as productive workers, was due not only to the Soviet state's limited abilities and the naive hubris of central planners. The environment also undermined Soviet intentions; natural responses to industrial interference reduced the state's control over the situation further.

The present essay also connects the experience of former kulaks to industrialization: a global phenomenon that helped cause their vulnerability to natural hazards. The Stalinist state took rapid industrialization as a non-negotiable imperative. Many scholars have commented on the obsession of Soviet policymakers with catching up the West. They root it variably in the practices of modern statecraft, legitimate economic needs, communist ideology, and a national pathos of Russia. ${ }^{10}$ It is also important to see Stalinist industrialization as a specific permutation of one of the most important global processes of the past two centuries.

In many places industrialization produced an increased vulnerability of social groups to natural hazards. Theoretical literature on vulnerability has emphasized that the outcomes of presumed natural calamities - such as famines, droughts, earthquakes, and climate change - are always embedded in social circumstances and existing political economy. ${ }^{\text {II }}$ Examinations of the social production of vulnerability often concentrate on a single disaster, but can extend to a more elusive array of risks. Piers Blaikie, Terry Cannon, Ian Davis, and Ben Wisner, for instance, elaborate several vulnerability-creating processes for biological hazards: conditions of the micro-environment such as diet, shelter, sanitation, and the water supply; migration and especially forced displacements; and the degradation and limited capacities of a physical environment. ${ }^{\mathrm{I} 2}$ All of these processes were at work in shaping the experience of the forced migrants in the Khibiny Mountains.

ı०. For example, see Hoffmann, Stalinist Values; Kotkin, Magnetic Mountain; Moshe Lewin, The Making of the Soviet System: Essays in the Social History of Interwar Russia (London, 1985); Alexander Gerschenkron, Economic Backwardness in Historical Perspective (Cambridge, MA, 1962); Andrzej Walicki, Marxism and the Leap to the Kingdom of Freedom: The Rise and Fall of the Communist Utopia (Stanford, CA, 1995); Martin Malia, Russia under Western Eyes: From the Bronze Horseman to the Lenin Mausoleum (Cambridge, MA, I999); idem, The Soviet Tragedy: A History of Socialism in Russia, I917-199I (New York, 1994).

I I. Michael J. Watts and Hans G. Bohle, "The Space of Vulnerability: The Causal Structure of Hunger and Famine", Progress in Human Geography, 17 (1993), pp. 43-67; Piers Blaikie et al., At Risk: Natural Hazards, People's Vulnerability, and Disasters (London, 1994); Jesse C. Ribot, "The Causal Structure of Vulnerability: Its Application to Climate Impact Analysis", GeoJournal, 35 (1995), pp. I 19-I 22; Greg Bankoff, Georg Frerks, and Dorothea Hilhorst (eds), Mapping Vulnerability: Disasters, Development, and People (London, 2004).

I2. Blaikie, At Risk, pp. 106-108. 


\section{THE KHIBINY MOUNTAINS AS A SITE OF GLOBAL INDUSTRIALIZATION}

The Soviet project in the Khibiny Mountains was part of a campaign to make the country an international power. It had its roots in the global ideologies of the time. The venture aimed at setting up apatite mines and processing plants on the Kola Peninsula (the Murmansk region) and constructing a socialist city from scratch north of the polar circle during the hectic first Five-Year Plan (1928-I932). Its history, therefore, fits just as much within the story of Stalinist industrialization in similar wellresearched cities like Magnitogorsk as within accounts of forced labor in the Soviet Union and the development of the Gulag. ${ }^{{ }^{3}}$

Soviet leaders considered industrialization necessary to render the country's economy more powerful, increase its defensive capacity, and bring it closer to modernity and communism. The conviction that modernization and socialist construction required industrial economic forms resonated with the teleological thought of the era. Contemporary versions of both Marxism and liberal economics took the industrialized countries of western Europe and North America as "advanced" in comparison to "backward" places like Russia and most of the rest of the world. In both of these modernist frameworks the natural environment was understood as an object of conquest and mastery that would be subdued by human ingenuity and rationality in the name of progress. The Bolsheviks embraced an innovation in Marxist theory that claimed that an avantgarde communist party could steer their country rapidly through historical stages. Russia would be able to acquire the material base of such advanced countries while avoiding the social structure and cultural superstructure of capitalism. ${ }^{14}$ Instead the Soviet Union would build "socialism in one country", in Stalin's memorable phrase, through rapid industrialization as a method of skipping stages of development.

Beyond the ideologies of the time that made industrial economies seem paramount, industrialization has also been one of the most transformative aspects of global environmental history. Understanding its Soviet variant can reveal much about how a large part of the world under a distinct political regime changed physically and socially. Stalinist industrialization involved the exclusive impetus of the state, the creation of a command

I3. Kotkin, Magnetic Mountain. Recent works that treat regional industrialization and forced labor are Nick Baron, Soviet Karelia: Politics, Planning and Terror in Stalin's Russia, 1920-1939 (London, 2007); James R. Harris, The Great Urals: Regionalism and the Evolution of the Soviet System (Ithaca, NY, 1999); Alan Barenberg, "From Prison Camp to Mining Town: The Gulag and its Legacy in Vorkuta, I938-1965" (unpublished Ph.D. dissertation, University of Chicago, 2007); Paul R. Gregory and Valery V. Lazarev (eds), The Economics of Forced Labor: The Soviet Gulag (Stanford, CA, 2003).

I4. Robert C. Tucker (ed.), The Lenin Anthology (New York, 1975). 
economy with centralized planning, and a revolutionary enthusiasm that positioned gritty development projects as springboards to communism. These features would later be transferred globally to other communist countries after World War II.

The Soviet Union in the r 930 also endeavored to create new industrial towns with forced labor. This program was meant to colonize extremely peripheral and sparsely populated territories and extract their natural resources. The scale of the endeavor, the pomp and circumstance that justified it, and the excess of the contradiction between the utopian visions and brutal reality distinguish it among industrial development schemes. Nevertheless, the situation at sites such as the one in the Khibiny Mountains reflects a global pattern; industrializing states often treated the natural environment primarily as an exploitable resource and produced heightened vulnerability among laboring populations.

Industrial interest in the Khibiny Mountains emerged in the r920s when the first systematic assessment of the geological content of the range revealed large veins of mixed apatite-nepheline ore in a massive igneous intrusion of nepheline rock. ${ }^{\mathrm{IS}}$ Apatite $\left(\mathrm{Ca}_{5}\left(\mathrm{PO}_{4}\right)_{3}(\mathrm{~F}, \mathrm{Cl}, \mathrm{OH})\right)$ is a form of calcium phosphate with an extra ion of fluorine, chlorine, or hydroxyl. It can be used to manufacture phosphate fertilizer. Soviet economic planners sought to turn this rock into chemical fertilizer in order to help reduce imports and create a new export commodity. They viewed adjustment to the trade balance as a necessary step to help capitalize other industrial projects. ${ }^{16}$ The expanded use of phosphate fertilizers could also increase agricultural productivity and help resolve the grain shortfalls that struck the country in $1927-1928 .^{17}$

The Khibiny Mountains were an extremely remote location at the time; the site of the apatite deposits was virtually uninhabited except for a few Sami reindeer herders who would come to the area to release their animals in the highlands for summer grazing. ${ }^{8}$ The lack of an available labor force in the region left open a variety of possibilities for how to exploit this resource. Initial ideas involved hiring temporary miners to extract the ore and then ship it to Leningrad on the nearby Murmansk railroad for processing. ${ }^{19}$ During the planning stage in 1929, the Unified State Political

I s. Victor Yakovenchuk et al., Khibiny (Apatity, 2005), pp. I-3 I.

I6. G.N. Solov'ianov, Kol'skii promyshlennyi uzel (Moscow, 1932).

17. Viola, The Unknown Gulag, p. I4.

I8. V.V. Charnoluskii, Materialy po bytu Loparei: opyt opredeleniia kochevogo sostoianiia Loparei vostochnoi chasti Kol'skogo poluostrova (Leningrad, 1930); A.E. Fersman, Nash Apatit (Moscow, 1968), p. 24.

19. Rossiiskii gosudarstvennyi arkhiv ekonomiki [hereafter, RGAE], f. 3 106 [Glavnoe upravlenie khimicheskoi promyshlennosti (Glavkhimprom) VSNKh SSSR], op. I/2, d. 367, 11. 62-79; A.V. Barabanov et al., Gigant v Khibinakh: Istoriia otkrytogo aktsionernogo obshchestva “Apatit” (1929-1999) (Moscow, 1999), p. I6. 


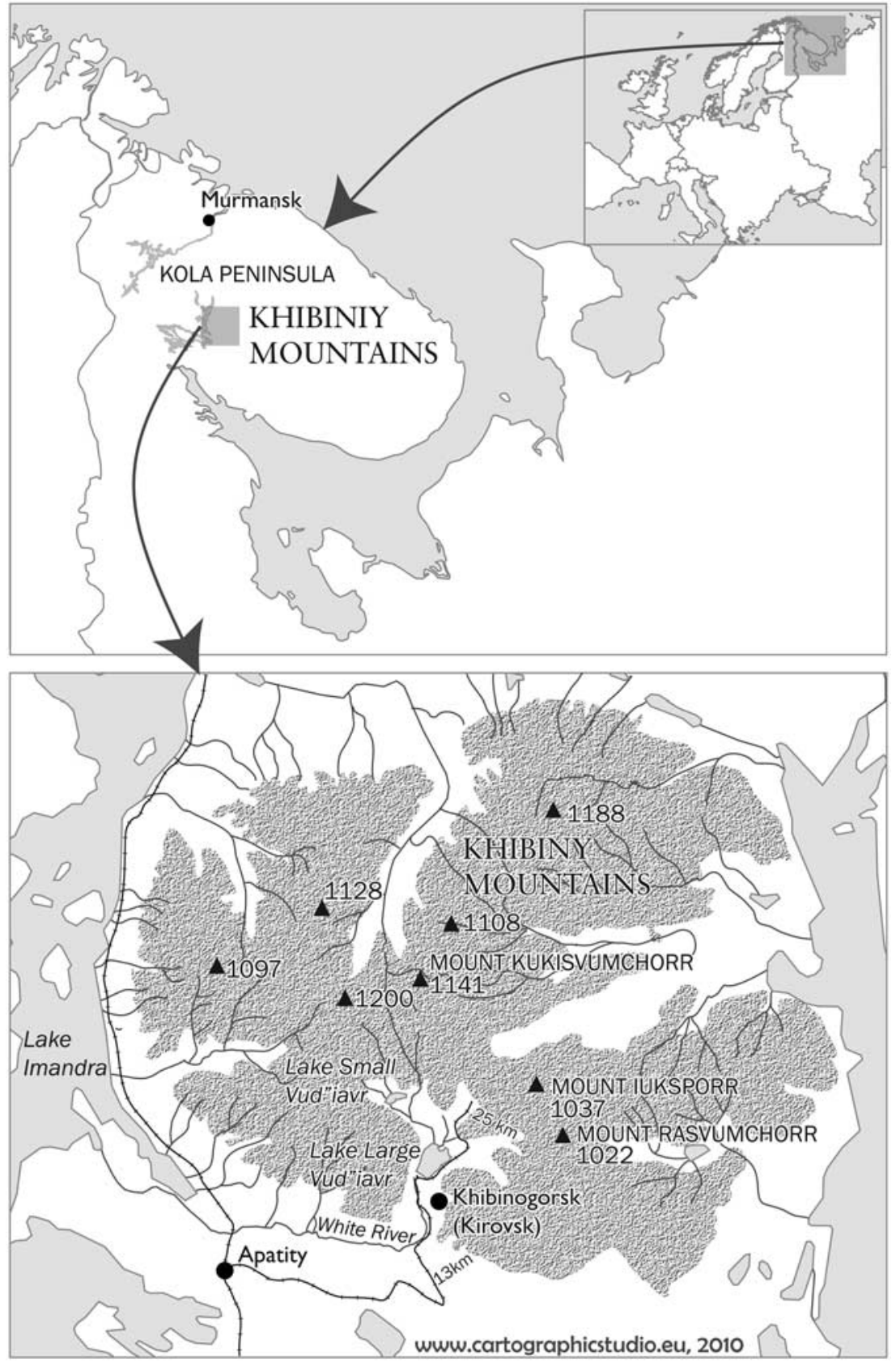

Figure 2. Map of the Khibiny Mountains. 
Administration (OGPU) made a bid to use prisoner labor to construct and operate the apatite works in the Khibiny Mountains. ${ }^{20}$ Government agencies ultimately rejected this proposal. Instead, revolutionary enthusiasm for the Stalinist Great Break inspired grandiose plans of building an entirely new socialist city in the region: one that would process the mined ore on site and strive to create an ideal communist environment, including harmony between proletarians and a subdued natural world. ${ }^{21}$ Ideas about how to supply adequate labor for the project remained vague at this point; the recruitment of voluntary workers and the selected use of contracted prisoners would supposedly meet the needs of the enterprise, the Apatit trust. ${ }^{22}$

Around the same time, the government commenced a campaign to reform rural Russia. The twin policies of collectivization and de-kulakization aimed at giving the state control of agricultural output, which had been market-based in the i920s. As part of a mass collectivization campaign during the winter of I929-1930, millions of comparatively welloff peasants became targeted as class enemies, kulaks. They were stripped of their property and excluded from membership in the new collective farms. The government slated a huge portion of these households for exile. Deportations began in the winter of 1930 at a time when there was no clear plan for resettlement, but only a general idea of using these dekulakized peasants to exploit natural resources in distant peripheries. Families arrived in new inhospitable and unfamiliar environments with minimal accommodations arranged. ${ }^{23}$

In April I930, OGPU head Genrikh Iagoda outlined the idea of turning these camps into more or less permanent self-sustaining "colonization settlements". Former kulak families would work in timber, agriculture, and mining, and help "colonize the north in the shortest possible time". ${ }^{24}$ This agency also specifically believed it was "impossible" to meet the needs of the Apatit trust by "hiring a free labor supply" because of the "remoteness and natural wildness of the Khibiny". ${ }^{25}$ Former kulak migrants, who became defined in state parlance as "special settlers" (spetspereselentsy), occupied an intermediate status between citizens and

20. “Chast' ofitsial'naia”, in A.E. Fersman (ed.), Khibinskie Apatity: Spornik, I (Leningrad, I930), pp. $28 \mathrm{I}-296,284-286$.

2I. Gosudarstvennyi arkhiv Murmanskoi oblasti [hereafter, GAMO], f. 773 [Lichnyi fond V.I. Kondrikova (1929-1936 gg.)], op. I, d. I, 11. I8, 107-108; M.D. Petrova, S.M. Salimova, and T.I. Podgorbunskaia (eds), Kirovsk $v$ dokumentakh i faktakh, I920-1945 gg. Khrestomatiia (Kirovsk, 2006), pp. 33-34.

22. GAMO, f. 773 , op. I, d. I, 11. 22, 100-106.

23. Viola, The Unknown Gulag, pp. I4-88.

24. Khlevniuk, The History of the Gulag, pp. 23-24.

25. Rossiiskii gosudarstvennyi arkhiv sotsial'no-politicheskoi istorii [hereafter, RGASPI], f. I7 [Tsentral'nyi komitet KPSS], op. I20, d. 26, 1. I 5 . 
labor-camp prisoners, being deprived of mobility and civil rights but contractually entitled to wages and (frequently unfulfilled) amenities. ${ }^{26}$

The special settlers became the main source of labor at this industrial site in the Khibiny Mountains. During the first few years of the I930s, more than 45,000 special settlers came to the Kola Peninsula, which had a total population of only 27,000 in 1927. All but a few thousand of them directly served the apatite works. ${ }^{27}$ In comparison to the majority of special settlers who worked in small isolated settlements for the forest industry, the labor needs of this project required greater integration of these forced migrants with the new socialist city of Khibinogorsk (Kirovsk after December 1934). In addition to the 6 special settlements outside the city and the ones serving the construction of the Niva Hydroelectric Station, close to 20,000 former kulaks in the Khibiny region lived in Khibinogorsk by $1933 .{ }^{28}$ The special settlers came from numerous places in the country, but the largest percentage of them was relocated from parts of the Leningrad region. Excluding the construction site of the Niva Hydroelectric Station, special settlers made up 69 per cent of the total population $(25,485)$ of the Khibiny region in October I93 I. At this point the gender ratio was near equal and 32 per cent were under 16 years old. ${ }^{29}$

\section{AN ENVIRONMENTAL INTERPRETATION OF “SPECIAL SETTLER" EXPERIENCE}

An investigation of the environmental contours of special-settler experience needs to begin by reintegrating a wide range of aspects firmly entrenched in existing knowledge about Stalinist social conditions into their natural contexts. Issues of housing, clothing, food, and hygiene, for instance, have obvious natural dimensions. Plants and animals nourish humans and supply materials; climatic phenomena and geographical features shape the needs, limitations, and possibilities of habitation. In the case of the Khibiny Mountains the long and snowy polar winter, the limited presence of building materials, the infertility of the soil, the dearth of flora and fauna for human foraging, the steep mountain relief of the worksite, the system of waterways, and the distance of the region from supply sources significantly affected the housing situation, the availability of basic domestic supplies, and special settlers' access to food and water. Nature occasionally exacerbated the situation as industrial activities caused

26. Viola, The Unknown Gulag, pp. 92-96; GAMO, f. 773, op. I, d. 6, 11. $230-232$.

27. V.Ia. Shashkov, Spetspereselentsy na Murmane: Rol' spetspereselentsev v razvitii proizvoditel'nykh sil na Kol'skom poluostrove (1930-1936 gg.) (Murmansk, I993), p. 32; idem, Spetspereselentsy $v$ istorii Murmanskoi oblasti (Murmansk, 2004), pp. I08-I I 3 .

28. Idem, Raskulachivanie v SSSR i sud'by spetspereselentsev, 1930-I954 gg. (Murmansk, I996), p. I67.

29. Petrova et al., Kirovsk v dokumentakh i faktakh, pp. 94-96. 
environmental changes such as pollution and increased avalanches, which in turn further influenced the living conditions of the special settlers.

In what follows, I examine the vulnerable situation created by state policy. I also assess the attempts of government and enterprise personnel to grapple with an environment not under their complete control and the ways that special settlers coped in harsh natural conditions.

The habitat that first greeted the forced migrants to the Khibiny region consisted of snowy mountain tundra with ad hoc housing of tents, mud huts, and shalmany. A hierarchical allocation of better accommodation first to freely recruited laborers meant that special settlers lived in these temporary dwellings longest. At one point in late 1930 after the winter had begun, close to I 2,000 of I 4,000 residents in the Khibinogorsk region lived in these types of houses. ${ }^{30}$ As numerous human families crowded into these dirty living spaces, pathogens causing diseases such as measles, typhus, typhoid fever, and tuberculosis spread throughout the population.

A condemning report from December 1930 by the regional inspector of housing and communal sanitation, I.A. Tikhomirov, claimed that the large portion of the current housing stock that "consists of shalmanov, mud huts, and tents, which act as surrogates of housing, is unacceptable for the conditions of the polar winter". Tikhomirov's overall assessment was that "the housing conditions of the population, particularly during an epidemic situation, are extremely unfavorable". The mud huts seem not to have survived the winter of 193 I here, but the other housing types and extremely crowded conditions lasted through the first Five-Year Plan. ${ }^{31}$ In 1934, Leningrad party boss Sergei Kirov wrote that special settlers in the Khibiny region only had I.9 square meters of space per person, considerably less than the desired three square meters per person. ${ }^{32}$

Polar nature further complicated the housing situation in the Khibiny Mountains. It exacerbated the endemic problems the Soviet state had in providing basic supplies to new industrial sites. ${ }^{33}$ The lack of suitable forest materials on the Kola Peninsula led the city to import wood from the Arkhang'elsk region. ${ }^{34}$ The Apatit trust also continually failed to fulfill its own plans for housing construction. ${ }^{35}$ The head of the enterprise,

30. A.V. Barabanov and T.A. Kalinina, "Apatit": vek iz veka (Apatity, 2004), p. 38.

3. Petrova et al., Kirovsk v dokumentakh i faktakh, pp. 60-6 I, 67; Shashkov, Spetspereselentsy $v$ istorii Murmanskoi oblasti, pp. 271-278.

32. GAMO, f. 773, op. I, d. 9, 11. 22-23,19I-193.

33. A contract between the main administration of camps of the OGPU and the Apatit trust from the summer of I93 I stipulated that the former had to supply funds for heating, illumination, and certain communal services for the special settlers and the latter was responsible for their housing, medical facilities, schools, and sanitation; GAMO, f. 773, op. I, d. 6, 11. 230-232. 34. Barabanov and Kalinina, "Apatit", p. 38.

35. RGASPI, f. I7, op. I20, d. 26, 1. 85; GAMO, f. 773, op. I, d. 5, 1. I90; GAMO, f. 773, op. I, d. 5, ll. 9-10; GAMO, f. 773, op. I, d. 44, 11. I9I-193. 


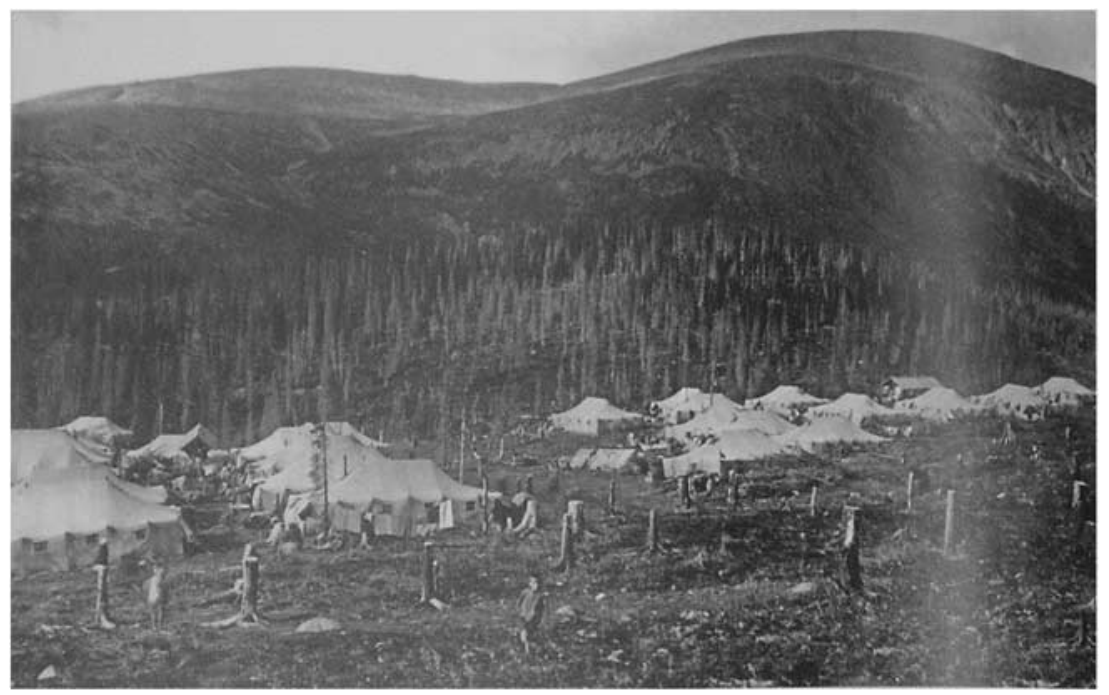

Figure 3. These tents, where families of "special settlers" had lived during a winter period, were built directly on top of a cleared section of forest.

Source: Tararaksin, Sudeb sgorevshikh ochertan'e [Outlines of Burnt Fates], p. II.

Vasilii Kondrikov, described the role of the Kola environment in inhibiting construction: "Unfortunately, large supplies of limestone on the Kola Peninsula have still not been found, there is comparatively little wood, the renewal period of which extends here up to 200 years, and until very recently there was a large deficit of clay." ${ }^{36}$ Trust leaders also explained their failures in housing construction as partially due to the "[h]arsh climate of the polar tundra", and "the mountain relief of the location with rocky ground". ${ }^{37}$

Moreover, special settlers who attempted to construct their own housing could not find adequate supplies. One report from I 934 summarized the situation for the special settlers: "there are no funds and also no construction materials - this means that there are no houses". ${ }^{8}$ The frequent forest fires along the Murmansk railroad and the near exhaustion of the limited wood supply near Lake Small Vud"iavr also limited special settlers' options for remedying the housing shortage themselves. After the production of concentrated apatite began in the fall of I93 I, dust from the enrichment factory started destroying local flora, which reduced available building material even further. ${ }^{39}$

36. V.I. Kondrikov, "Sostoianie i perspektivy stroitel'stva v raione Khibinskikh razrabotok", Karelo-Murmanskii krai, 5-6 (I93I), pp. 7-13, 9.

37. Petrova et al., Kirovsk v dokumentakh i faktakh, p. 66.

38. Shashkov, Spetspereselentsy v istorii Murmanskoi oblasti, p. 277.

39. GAMO, f. 773 , op. I, d. 51, 1. 92. 
For the eight to nine months of the year when temperatures in the Khibiny Mountains were below freezing, snow acted as a dangerous environmental influence. The area had an annual average of over i 60 days of snowstorms a year and significantly greater snow cover than other parts of the Kola Peninsula. ${ }^{40}$ The mountainous terrain already made the potential for avalanches of snow and boulders especially great. The use of industrial explosions in the mines during the long winter heightened this risk. ${ }^{4 \mathrm{I}}$ From 1933 to 1938 observers recorded about 300 avalanches, which destroyed buildings and caused injuries and death. ${ }^{42}$ A major avalanche from Mount Iuksporr on 5 December 1935 destroyed two buildings, which housed 249 people, and killed 89 individuals, including 46 special settlers. ${ }^{43}$ State and industrial planners clearly contributed to making the migrants vulnerable to this disaster by deciding to place the settlement in an area known to be avalanche-prone. ${ }^{44}$ This catastrophe inspired an active campaign in the city to monitor and prevent avalanches, but their continued threat limited the locations of new settlements in the long run. ${ }^{45}$

The special settlers also often lacked basic items necessary for survival in such a cold climate. The government had stripped them of most of their property except for a bit of money and some clothing and equipment for agriculture, construction, and cooking. The frequently violent expropriations of the de-kulakization campaign left many peasant families with much less than the sanctioned norms. ${ }^{46}$ To augment the clothing and tools brought by the migrants, the trust and the city government petitioned for special winter clothing, set up occasional open fairs, and established a few stores. The supply system in the Khibiny region managed to procure a somewhat reasonable level of some of the required clothing such as

40. B.K. Odovenko and R.M. Gamberg, "Sovershenstvovanie tekhnologii otkrytoi razrabotki moshchnykh rudnykh zalezhei”, in I.A. Turchaninov (ed.), Osvoenie mineral'nykh bogatstv Kol'skogo poluostrova (Murmansk, 1974), pp. 20-45, 24.

4I. P.V. Vladimirov and N.S. Morev, Apatitovyi rudnik im. S.M. Kirova (Leningrad, 1936), pp. I 20-I 2 I.

42. B.M. Belen'kii, "Iz istorii issledovaniia snega i lavin v khibinakh", in E.Ia. Zamotkin and N.M. Egorova (eds), Priroda i khoziaistvo Severa, II, part 2 (Apatity, I97I), pp. 305-3 I0, 306; Vladimirov and Morev, Apatitovyi rudnik im. S.M. Kirova, pp. I I I-I 2 I.

43. Petrova et al., Kirovsk $v$ dokumentakh i faktakh, pp. IоI-IO2; S.N. Boldyrev, "Lavina s gory Iukspor", in G.I. Rakov (ed.), Khibinskie klady: Vospominaniia veteranov osvoeniia Severa (Leningrad, I972), pp. 290-300.

44. G.F. Smirnov, "Obogashchenie apatito-nefelinovoi porody Khibinskogo mestorozhdeniia", in Fersman, Khibinskie Apatity, I, pp. I22-I39; Arkhiv Rossiiskoi Akademii Nauk [hereafter, ARAN], f. 544 [Lichnyi fond A.E. Fersmana], op. I, d. 334, ll. I-6; GAMO, f. 773, op. I, d. I, 11. I07-I08, I 49-I 54 .

45. Belen'kii, "Iz istorii issledovaniia snega i lavin v khibinakh", in Zamotkin and Egorova, Priroda $i$ khoziaistvo Severa, II, part 2, pp. 305-310.

46. Viola, The Unknown Gulag, pp. 33-44. 
leather shoes, felt boots, underwear, suits, coats, bags, sheets, and hats by late $1930 .{ }^{47}$ However, as forced and voluntary migrants continued to flow to the worksite, these efforts failed to overcome the chronic lack of sufficient items needed for living, working, and staying warm in the tundra. As special settler F.B. Zubkova later summarized it succinctly: "In material terms, we lived poorly." 48

Food shortages characterized life in the Khibiny region throughout the I930s. They occurred despite the contractual obligations of the trust and the secret police to supply the special settlers with sufficient food provisions and the settlement's proximity to the Murmansk railroad, which facilitated food shipments. ${ }^{49}$ The state and party organs in Khibinogorsk attempted to procure foodstuffs through several organizations, including a Closed Workers' Cooperative and a special trust to manage imports. Like elsewhere in the country, they also set up a network of cafeterias where people ate most of their meals. Far short of supplying the statesanctioned rations, these institutions were only minimally effective in helping to prevent the population from starving..$^{\circ}$

The natural conditions of this rocky polar land inhibited efforts to feed the special settlers adequately. The infertility of the soil, the region's alpine elevation, and the short growing season characteristic of such latitudes made agriculture nearly impossible here. Indeed, scientists only conclusively established the possibility of growing certain vegetables in the I920s and grain cultivation never became a viable option. ${ }^{5 \mathrm{I}}$ Given these environmental constraints, it is hardly surprising that the initial attempts of the Apatit trust to organize local agriculture were largely unsuccessful. The state farm "Industriia", where a number of special settlers worked, spent its first years on land reclamation, farming only a few hectares of land. The meat and milk economy of the state farm also suffered from a lack of shelters for livestock, which caused many animals to freeze to death. ${ }^{52}$

Some special settlers in the Khibiny region dealt with these shortages by making use of natural elements familiar to them in a new environment. The migrants caught freshwater fish in the nearby lakes and rivers and collected mushrooms and berries in the summer. One special settler,

47. GAMO, f. 773, op. I, d. 2, 11. I83-186; Petrova et al., Kirovsk v dokumentakh i faktakh, pp. 64-65, 68-69.

48. F.B. Zubkova, “Opiat' nas ushchemliaiut”, in Spetspereselentsy v Khibinakh, pp. 19-2 I, 20.

49. GAMO, f. 773 , op. I, d. 6, 11. 230-232.

50. Petrova et al., Kirovsk v dokumentakh i faktakh, pp. 68-74; and GAMO, f. 773, op. I, d. I 5 , 11. $76-79$.

5 I. S.A. Diuzhilov, "Nauchnoe reshenie problemy poliarnogo zemledeliia", in P.V. Fedorov, Iu.P. Bardileva, and E.I. Mikhailov (eds), Zhivushchie na Severe: Vyvoz ekstremal'noi srede (Murmansk, 2005), pp. 82-86.

52. Petrova et al., Kirovsk v dokumentakh i faktakh, pp. 54, 74-75. 
L.D. Zverev, later described the tactics employed by his family at the time:

Father made nets. We had ponds around home and there were many fish. $\mathrm{He}$ was a craftsman and made nets. He went into the mountains where there were already pools and caught fish. He goes out for mushrooms and fetches netting and fish. The fish is good. And there was perch where the airdrome is. He also goes there and catches. In the White River there used to be a lot of fish, only they've gone away. In this way we didn't starve. ${ }^{53}$

In the first years after their arrival many families supplemented their diets with aquatic fauna that they obtained outside the state-sponsored distribution system. However, in the fall of 193 I Apatit began dumping massive amounts of wastewater from enrichment processing into the White River. ${ }^{54}$ This industrial pollution soon killed off the fish there and eliminated this source of food for the special settlers. ${ }^{55}$

A famine in 1932-1933 hit the grain-producing regions of the country, especially Ukraine, the hardest. However, the special settlements also suffered terribly both from lack of food and ruthless government action. An immediate response of the central authorities was to reduce food rations for special settlers, thereby guaranteeing further suffering among this population. ${ }^{56}$ A 1934 report of the Khibinogorsk City Council, after ration levels had been restored, revealed a continued insufficiency in the diets of workers and their families. The lack of food led some to flee; others died of starvation. Food shortage also resulted in widespread incidents of diseases caused by malnourishment. The specific conditions of the Khibiny environment played a role here in the scurvy outbreaks and the fact that 70 per cent of children suffered from rickets in 1934. The lack of local fruits and vegetables inhibited vitamin C intake, causing scurvy, and the long sunless months and insufficient dairy consumption likely led to vitamin $\mathrm{D}$ deficiencies, giving rise to rickets. ${ }^{57}$

Impediments posed by the natural features of the Khibiny Mountains for simultaneously organizing industrial and drinking water supplies and sewage removal negatively affected the health and livelihood of the special settlers. Throughout I930, urban and enterprise planners struggled to align their idealistic visions for the socialist city of Khibinogorsk with

53. L.D. Zverev, "Rasskaz o zhizni bogatoi", in Spetspereselentsy v Khibinakh, pp. I I-18, i6. 54. Barabanov et al., Gigant v Khibinakh, pp. 44-59, and S.A. Diuzhilov, "'Aripelag Svobody" na Murmane (vtoraia polovina 1920-kh-1930-e g.g.)”, in P.V. Fedorov et al. (eds), Zhivushchie na Severe: obrazy i real'nosti (Murmansk, 2006), pp. 93-100, 100.

55. ARAN, f. 544, op. I, d. I6I, 11. 40-42; GAMO, f. 773, op. I, d. 51, 11. 92-94.

56. Viola, The Unknown Gulag, pp. I32-I49.

57. Shashkov, Spetspereselentsy v istorii Murmanskoi oblasti, pp. 278-279; GAMO, f. R-163 [Otdel zdravookhraneniia pri ispolnitel'nom komitete Murmanskogo okruzhnogo soveta (1927-I937 gg.)], op. I, d. I4I, l. I3. 
practical considerations. They wanted to use the local water system as both a source and a dump and minimize infrastructure costs. ${ }^{8}{ }^{8}$ None of the options they considered during that year seemed entirely satisfactory. ${ }^{59}$ However, they eventually chose to build both the town and the enrichment plant of Apatit along the southern shore of Lake Large Vud"iavr. Since industrial waste would be dumped into the White River, which flowed downstream out of Lake Large Vud"iavr, enterprise leaders hoped this model would preserve the lake water as safe for drinking. ${ }^{60}$

When the special settlers first arrived in 1930, they immediately began drawing water from the sources closest to their settlements for drinking, cooking, cleaning, bathing, and extinguishing fires. They often filled barrels with water from lakes and rivers or built temporary pipes that froze in the winter. Furthermore, in what became a chronic problem for many years in the Khibiny region, various sources of human contamination from laundry, trash receptacles, cesspits, and used water from the bathhouses began to pollute the water supply. Even without industrial dumping, these everyday forms of pollution already made the unpurified water far from clean. As sanitation inspector Tikhomirov wrote at the end of 1930 :

Independent of the results of the study [on the bacteriologic content of the water] one can already now count all of the available sources of a water supply as to a greater or lesser degree contaminated, the mountain character of the place with a sharp incline represents an almost insuperable obstacle to the protection of them from pollution. ${ }^{61}$

As diseases connected to contaminated water gripped Khibinogorsk and its outlying settlements in I93 I-1932, the local government attempted to regulate migrants' use of water. They often relied on draconian measures that sought to place the burden of environmental protection on the forced migrants instead of the industrial enterprise or the city's administration. One resolution of the Khibinogorsk City Council from I93 I created a 50-meter territory around Lake Large Vud"iavr that was to be on a "strict regime" of reduced human activity and construction for the sake of preserving this water source. ${ }^{62}$ Another resolution of the City

58. N.N. Vorontsov, "Khibinskoe stroitel'stvo", in A.E. Fersman (ed.), Khibinskie Apatity: Sbornik, II (Leningrad, I932), pp. I82-I9I; O.R. Munts, "Gorod Khibinogorsk i ego planirovka”, in ibid., pp. 192-207; GAMO, f. 773, op. I, d. I, ll. 107-108; Petrova et al., Kirovsk v dokumentakh i faktakh, pp. 33-34.

59. GAMO, f. 773, op. I, d. I, ll. I49-I 54 .

60. Munts, "Gorod Khibinogorsk i ego planirovka", pp. 192-207; Petrova et al., Kirovsk v dokumentakh $i$ faktakh, pp. 33-34; Smirnov, "Obogashchenie apatito-nefelinovoi porody Khibinskogo mestorozhdeniia”, pp. I 22-I 39.

6. Petrova et al., Kirovsk $v$ dokumentakh i faktakh, pp. 62-63.

62. GAMO, f. R-I63, op. I, d. 26, 1l. I 5-16. 


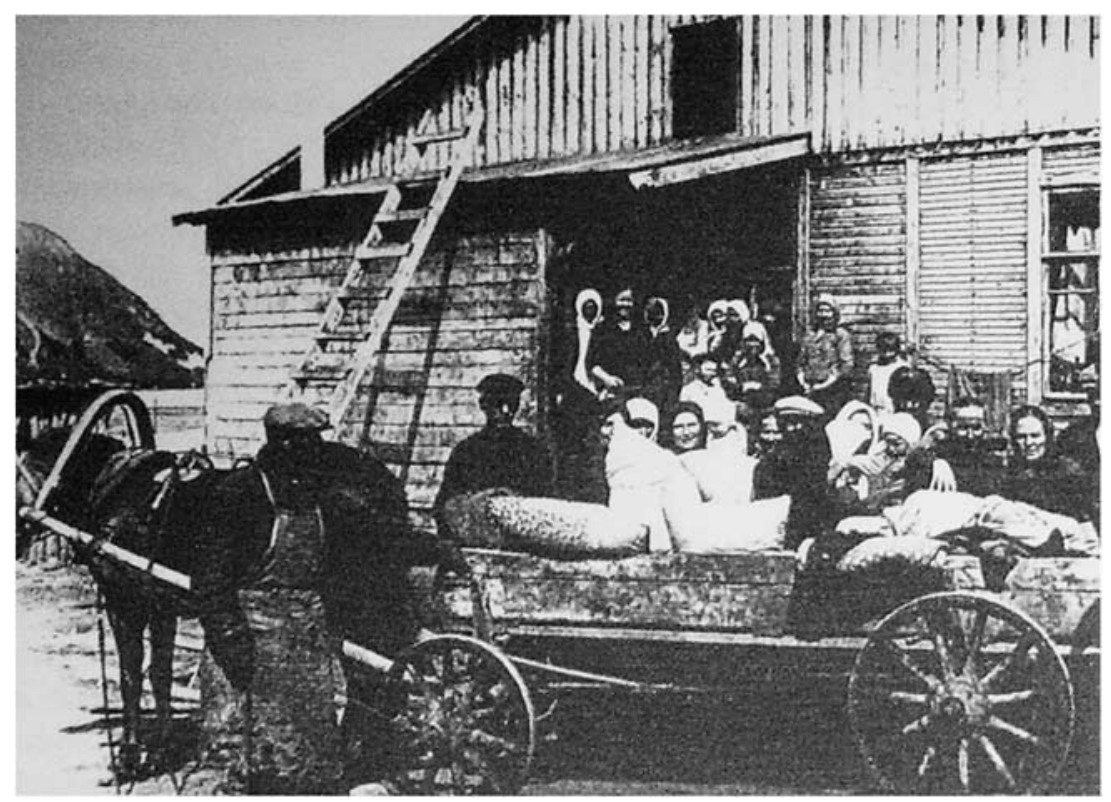

Figure 4. This picture shows a group of "special settlers" gathering their laundry to wash. Source: Tararaksin, Sudeb sgorevshikh ochertan'e [Outlines of Burnt Fates], p. 28.

Council from 21 August I93 I aimed at sanitary protection of the water supply. One hundred copies of it were printed and presumably posted around the area. The decree prohibited dumping wastes on the ground, placing cafeterias, bathhouses, cesspits, lavatories, stables, and pigsties within 50 meters of any water body, doing laundry in living quarters, and taking water from a specific lake and river for any reason besides housing construction. ${ }^{63}$ Eventually, the city began on-site chlorination of drinking water drawn from a water body that was already polluted. ${ }^{64}$ In later years the authorities tried to limit the number of trips special settlers made to the bathhouses and accused individuals who reused their tickets of subversive behavior. ${ }^{65}$

The steep tundra mountains and the existing water system of the area confounded industrialists' schemes for organizing the territory's hydrology to their maximum benefit. The regime's unwillingness to prioritize sewer construction and the effects of industrial pollution added to the difficulties with arranging a water supply for the new settlement. At the

63. GAMO, f. R-163, op. I, d. 26, 1. I7.

64. Petrova et al., Kirovsk v dokumentakh i faktakh, p. I 5.

65. Shashkov, Spetspereselentsy v istorii Murmanskoi oblasti, p. 283. 
end of 1930 the Apatit trust still intended to begin construction on a sewer system, water pipe, and purification station during I93I; the drinking water source in this plan would come from the river Loparki and not Lake Large Vud"iavr, which would be the source only for industrial water. ${ }^{66}$ However, as the enterprise lagged in its production quotas, such basic municipal expenditures as the provision of a safe water service were repeatedly deferred. ${ }^{67}$

This postponement delayed the construction of a sewer system until after Apatit had polluted the water of the White River and Lake Large Vud"iavr with byproducts from enrichment. This pollution changed the chemical character of the water and made it even less suitable for domestic use by special settlers. ${ }^{68}$ Furthermore, without a pipe system to supply water the ability to extinguish fires that arose at industrial sites or in crowded wooded housing was virtually non-existent. ${ }^{69}$ As a City Council report put it in 1934: "There are a lot of unsanitary conditions and the fire prevention situation is unsatisfactory - there is no water." ${ }^{\circ} \mathrm{By}$ this point the party leaders in Leningrad had also become somewhat more attentive to the problems with water in the Khibiny region. Kirov wrote to the People's Commissariat of Heavy Industry and the State Planning Committee in 1934:

In Khibinogorsk and its settlements there is a complete lack of a sewer system and it does not have an independent system of municipal water supply - the supply of the city is produced with unpurified water from Lake Large Vud"iavr through a pumping station of the industrial water supply. Further postponing the urgent construction and the sewer system might bring the population to mass diseases of an epidemic character. ${ }^{7 \mathrm{I}}$

Construction of these services did finally begin the next year, but only near the end of the decade did they even approach completion. ${ }^{72}$

66. Petrova et al., Kirovsk $v$ dokumentakh i faktakh, p. 63.

67. GAMO, f. 773, op. I, d. 5, 11. 62-70, I92-193; Barabanov et al., Gigant v Khibinakh, p. 51; GAMO, f. 773, op. I, d. 51, ll. 92-94.

68. GAMO, f. 773 , op. I, d. 5 I, 11. $84-100$.

69. Ivan Kataev offers a vivid description of a fire in Khibinogorsk from this period; Ivan Kataev, "Ledianaia Ellada”, in B.I. Nikol'skii and Iu.A. Pompeev (eds), Pul's Khibin (Leningrad, 1984), pp. 42-66, 52-53.

70. Shashkov, Spetspereselentsy v istorii Murmanskoi oblasti, p. 278.

71. GAMO, f. 773, op. I, d. 9, ll. 192-193.

72. Petrova et al., Kirovsk v dokumentakh i faktakh, pp. I43-I46. The Axis powers extensively bombed Kirovsk during World War II. The destruction of the town means that most likely the sewer system only began functioning again in the late I940s or early I950s. On sewage issues in postwar Soviet cities, see Donald Filtzer, "Standard of Living versus Quality of Life: Struggling with the Urban Environment in Russia During the Early Years of Postwar Reconstruction", in Juliane Fürst (ed.), Late Stalinist Russia: Society Between Reconstruction and Reinvention (London, 2006), pp. 81-102. 


\section{THE CONSEQUENCES FOR THE "SPECIAL SETTLERS”}

The species of fauna known as homo sapiens could not initially thrive in the habitat created by Stalinist industrialization and forced deportations. The circumstances, from the proximate cesspits to the crowded dwellings, were a nightmare for human health. As one special settler, Aleksandra Iablonskaia, recalled decades later: "Only at night could I find a place. If you arrived late, you would sleep on the edge in the cold. [...] I crept among the sick in the cold and dirt." ${ }^{3}$

A meeting of doctors in Khibinogorsk in September I93 I proposed limiting the number of people per tent to 40 or 45 based on their overall assessment of the situation at the special settlement at the i8-kilometer mark: "The contamination of the settlement with garbage, overcrowding, the absence of a basic stock of everyday items and the dirtiness of the area undoubtedly is a favorable atmosphere for the development of disease." ${ }^{\prime 4}$ A few months later, in February 1932, a report on the living conditions at the mining settlements of Iuksporiok and Rasvumchorr revealed the totality of the poor sanitary conditions there: unclean barracks with poor stoves, doors, and windows, an unsafe water supply, poor illumination, freezing temperatures, and outbreaks of disease. ${ }^{75}$

The local environment combined with the oppressive development model of the Soviet state to produce conditions of widespread disease and death among those individuals who did not escape. Children suffered disproportionately. The new residents in the Khibiny region fell ill with diseases similar to those that hit other special settlements in the north, including typhus, typhoid fever, tuberculosis, scurvy, and measles. ${ }^{76}$ The available data on the incidence of these diseases are largely anecdotal. Over 175 children died from measles in September and October 1930, doctors reported 55 new cases of typhoid fever in the late summer of I93 I at one of the outlying settlements, and 20 children in Iablonskaia's shalman died of typhus. ${ }^{77}$ These diseases raged throughout the area into 1932 and then began to subside. Starting in this year doctors in the area managed to administer thousands of inoculations against typhoid, smallpox, and diphtheria, which primarily accounted for the improvement despite the continued lack of municipal infrastructure necessary for urban sanitation. ${ }^{78}$

73. Tat'iana Shishkina, "Iablonskie", Khibinskii vestnik (s October 2006), p. 6.

74. GAMO, f. R-163, op. I, d. 26, 11. 8-10.

75. GAMO, f. 773, op. I, d. Is, ll. 98-101.

76. Viola, The Unknown Gulag, pp. 34-14I, and A.A. Kiselev, "GULAG na Murmane: Istoriia tiurem, lagerei, kolonii", Sovetskii Murman (8 October 1992), p. 3.

77. Barabanov and Kalinina, "Apatit”, p. 38; GAMO, f. R-163, op. I, d. 26, 11. 8-10; Shishkina, "Iablonskie", p. 6.

78. Petrova et al., Kirovsk $v$ dokumentakh i faktakh, pp. I $52-153$. 
Table r. Demography of Khibinogorsk/Kirovsk.

\begin{tabular}{|c|c|c|c|c|c|c|c|}
\hline Date & $\begin{array}{c}\text { Total } \\
\text { population }\end{array}$ & $\begin{array}{c}\text { Special } \\
\text { settler } \\
\text { population }\end{array}$ & $\begin{array}{c}\text { Total births } \\
\text { (previous } \\
\text { year) }\end{array}$ & $\begin{array}{l}\text { Special settler } \\
\text { births } \\
\text { (previous year) }\end{array}$ & $\begin{array}{c}\text { Total deaths } \\
\text { (previous } \\
\text { year) }\end{array}$ & $\begin{array}{c}\text { Special settler } \\
\text { deaths } \\
\text { (previous year) }\end{array}$ & $\begin{array}{c}\text { Deaths of } \\
\text { children } \\
\text { (previous year) }\end{array}$ \\
\hline 1 January 1932 & 24,485 & 17,756 & 564 & 420 & 999 & 864 & 589 \\
\hline 1 January 1933 & 28,500 & 19,172 & 856 & 506 & 860 & 657 & 339 \\
\hline 1 January 1934 & 34,332 & 19,731 & 717 & 374 & 850 & 518 & 352 \\
\hline 1 January 1935 & 36,957 & 21,325 & 718 & 310 & 620 & 401 & 192 \\
\hline
\end{tabular}

Source: Shashkov, Spetspereselentsy $v$ istorii Murmanskoi oblasti, pp. I43, I9I. 
Table 2. Birth and death rates in Khibinogorsk/Kirovsk.

\begin{tabular}{lcccccc}
\hline Year & $\begin{array}{c}\text { Special } \\
\text { settler birth } \\
\text { rate }(\%)\end{array}$ & $\begin{array}{c}\text { Non-special } \\
\text { settler birth } \\
\text { rate }(\%)\end{array}$ & $\begin{array}{c}\text { Total } \\
\text { birth } \\
\text { rate }(\%)\end{array}$ & $\begin{array}{c}\text { Special settler } \\
\text { death rate } \\
(\%)\end{array}$ & $\begin{array}{c}\text { Non-special } \\
\text { settler death } \\
\text { rate }(\%)\end{array}$ & $\begin{array}{c}\text { Total } \\
\text { death } \\
\text { rate }(\%)\end{array}$ \\
\hline 1931 & 2.4 & 2.1 & 2.3 & 4.9 & 2.0 & 4.1 \\
1932 & 2.6 & 3.8 & 3.0 & 3.4 & 2.2 & 3.0 \\
1933 & 1.9 & 2.3 & 2.1 & 2.6 & 2.3 & 2.5 \\
1934 & 1.5 & 2.6 & 1.9 & 1.9 & 1.4 & 1.7 \\
\hline
\end{tabular}

Source: Shashkov, Spetspereselentsy v istorii Murmanskoi oblasti, pp. I43, I9I.

For many special settlers the final outcome of all of these natural phenomena of disease, hunger, cold, and filth in the Khibiny region was death. Special settler V.M. Lebedik later drew connections among these factors: "It is hard to say how many people lived in this barrack. There was no thought about hygiene. Diseases began and every morning we brought out the dead." 79 In 1935 a health inspector in the region, A.G. Friliand, noted that the mortality rate, especially for children, at this new site of socialist modernity was considerably higher than the Soviet average. ${ }^{80}$ Aggregate figures showing overall deaths in the Khibiny region remain elusive. However, the historian Victor Shashkov has pieced together some demographic data for the city of Khibinogorsk, the population of which had a smaller percentage of special settlers than the other settlements in the region. The figures for the surrounding settlements were almost certainly worse.

The data in Table I show a total of 3,329 deaths, 2,440 among the population of special settlers and I,472 children, from I93 I through I 934 in Khibinogorsk. Children made up 44.2 per cent of those who perished in these years, though this percentage declined from a particularly dreadful 59 per cent for I93 I to 3I per cent for 1934. The figures in Table 2 also reveal a general trend of improvement in the rate of mortality. Interestingly, over this period both the birth rate and death rate of settlers gradually declined. The death rates of 4.9 per cent for the special settlers for I 93 I and 3.4 per cent for 1932, compared with the 2 per cent for the remaining population for 193 I and 2.2 per cent for 1932 , demonstrate the disproportional suffering of these forced migrants over freely recruited laborers and enterprise administration.

\section{CONCLUSION}

In the I930s, Soviet government embraced what was arguably the greatest economic imperative of globalization at the time, industrialization, with a 
foolhardy enthusiasm that helped lead to extreme human suffering. Its reliance on forced labor on multiple scales is a story already well told. Scholars have paid less attention, however, to how the natural environment was a fundamental component of this history.

The environment contributed to the creation of intolerable conditions for the special settlers through the imposition of relatively stable obstacles (cold weather, for instance) and through changes in response to human activity (polluted water, for example). In doing so it thwarted the intentions of state planners, who could not fully control nature despite their desires, and added to the chaos of Stalinist industrialization. One thing that the policy of forcefully sending declassed peasants to build a socialist mining town in the far north accomplished, however, was the creation of extreme vulnerability of the special settlers to hazards within their new natural environment. This perilous situation produced tragic results for many of the individuals sent to live and labor at the apatite works in the Khibiny Mountains. 